\title{
Joga w czasach zarazy - możliwości i wyzwania praktykowania jogi online przez osoby z dysfunkcją wzroku
}

Kamila Albin

(D) https://orcid.org/0000-0002-2846-8751 Uniwersytet Warszawski 


\title{
Streszczenie
}

W artykule zaprezentowano praktykę jogi zainicjowaną przez osoby z dysfunkcją wzroku w czasie lockdownu, prowadzoną z wykorzystaniem technologii informacyjno-komunikacyjnych.

Celem analizy jest ukazanie, jakie możliwości dają osobom niewidomym i słabowidzącym narzędzia komunikacji zdalnej w zakresie uprawiania sportu, szczególnie do praktykowania jogi. Autorka zastanawia się, jakie wyzwania niesie ze sobą za pośredniczenie ćwiczeń i kontaktu z nauczycielem przez platformy cyfrowe, takie jak Zoom. W tekście ukazano także perspektywę nauczycielek jogi, prowadzących zajęcia z osobami z niepełnosprawnością wzroku. Odpowiada na pytanie, jakie wyzwania wiążą się dla nich w pracy z tą grupą, jakie nowe umiejętności w zakresie nauczania jogi musiały rozwinąć.

Autorka stawia pytanie, czy ten sposób praktykowania jogi może mieć jakąś przewagę nad ćwiczeniami w szkole jogi. Na postawione powyżej pytania poszukuje odpowiedzi, posługując się metodą autoetnografii analitycznej. W tekście łączą się różne perspektywy wglądu w doświadczenie ćwiczenia jogi: badaczki-socjolożki i osoby z niepełnosprawnością, innych osób uczestniczących w zajęciach oraz nauczycielek jogi.

\section{Słowa kluczowe}

autoetnografia analityczna, autoetnografia ewokatywna, joga, niepełnosprawność wzroku, technologie informacyjno-komunikacyjne.

\section{Yoga in the Time of Plague - Opportunities and Challenges for Visually Impaired persons to Practice Yoga Online}

\begin{abstract}
This paper discusses yoga practice initiated during lockdown by visually impaired people using information and communication technology. The aim of the analysis is to show what possibilities remote communication tools offer blind and visually impaired people in terms of sport, especially in relation to the practice of yoga. The author reflects on the challenges of mediating exercise and contact with the teacher through digital platforms such as Zoom. The article also uncovers the perspective of yoga teachers who conduct classes with visually impaired people. It addresses the issue of challenges they face in working with this group and new skills in teaching yoga they have had to develop. The author poses the question as to whether this way of practicing yoga can have any advantage over practicing in a yoga school. The author explores answers to the questions posed above using the method of analytical autoethnography. The paper combines different perspectives of insight into the experience of practicing yoga: that of a researcher, a sociologist and a person with disabilities, and that of other people participating in classes and yoga teachers.
\end{abstract}

\section{Keywords}

analytical autoethnography, evocative autoethnography, information and communication technologies, visual impairment, yoga. 
Dandemia koronawirusa sprawiła, że nagle, praktycznie z dnia na dzień, rozpędzony świat gwałtownie wyhamował. Wraz z ogłoszeniem lockdownu większość z nas musiała przenieść swoje dotychczasowe aktywności, takie jak nauka i praca, do sieci. Oprócz oczywistych ograniczeń wynikających z niemożności spotykania się twarzą w twarz, sytuacja ta otworzyła przed nami nowe możliwości wykorzystania potencjału wirtualnej przestrzeni. Pojawiły się zdalne formy korzystania z dóbr kultury, np. możliwość uczestnictwa w pokazach filmowych, spektaklach teatralnych online, a także zdalne uprawianie sportu, np. jogi, pilatesu, fitness w „wirtualnym towarzystwie” youtuberów, organizujących treningi na żywo czy umieszczających na swoich kanałach filmy z gotowymi zestawami ćwiczeń. Nie ma wątpliwości, że pandemia znacząco wpłynęła także na aktywności osób niepełnosprawnych we wszystkich wymienionych obszarach i że każdy z nich zasługuje na badawczą uwagę. Łącząc perspektywy badaczki-socjolożki i osoby z niepełnosprawnością w artykule przyjrzę się zainicjowanej oddolnie przez osoby z niepełnosprawnością wzroku grupie ćwiczącej jogę online, w której sama jestem od początku jej istnienia. Jak zauważa Agata Stasińska (2020) do tej pory w polskiej socjologii nie poświęcano wiele miejsca praktyce jogi i jej związkom z życiem społecznym jednostki. Na uwagę zasługuje socjologiczna monografia Krzysztofa Koneckiego, w której badacz m.in. charakteryzuje jogiczną społeczność w Polsce (Konecki, 2012). Moim celem jest ukazanie, jakie możliwości dają osobom niewidomym i słabowidzącym narzędzia komunikacji zdalnej w zakresie uprawiania sportu, w tym kontekście szczególnie w odniesieniu do praktykowania jogi. Przeanalizuję, jakie wyzwania niesie ze sobą zapośredniczenie ćwiczeń i kontaktu z nauczycielem przez platformy cyfrowe, takie jak Zoom. Zaprezentuję także perspektywę nauczycielek jogi prowadzących zajęcia z osobami z niepełnosprawnością wzroku. Odpowiem na pytanie, jakie wyzwania wiążą się dla nich w pracy z tą grupą, jakie nowe umiejętności w zakresie nauczania jogi musiały rozwinąć.

Zastanowię się także, czy ten sposób praktykowania jogi może mieć jakąś przewagę nad ćwiczeniami w szkole jogi.

\section{MIĘDZY AUTOETNOGRAFICZNĄ EWOKACJĄ I ANALIZĄ}

Ze względu na moje zakorzenienie w grupie osób ćwiczących jogę, a także chęć połączenia różnych perspektyw wglądu w doświadczenie praktykowania jogi, najbardziej adekwatną strategią badawczą wydaje się być podejście autoetnograficzne. Może ono przybierać różne formy. Jednym ze sposobów uprawiania autoetnografii oraz konstruowania autoetnograficznej narracji badacza jest tzw. autoetnografia ewokatywna (ang. evocative autoetnography). Jej sednem jest koncentracja na przeżyciach badacza, jego emocjach, myślach, postrzeżeniach, do których dociera przez akt głębokiej introspekcji, a dopiero potem poprzez swoją subiektywność próbuje uchwycić społeczne i kulturowe elementy świata życia codziennego (Bielecka-Prus, 2014). Autoetnografia ewokatywna rozumiana jako specyficzna praktyka narracyjna może przybierać formę pisanych w pierwszej 
osobie tekstów: osobistych esejów, poezji, socjologicznej prozy naukowej, a także performansu. Takie wykorzystanie autoetnografii służy nie tyle przekazaniu twardej, pewnej wiedzy czy precyzyjnemu objaśnieniu mechanizmów rządzących światem społecznym, co raczej wywołaniu u odbiorców przeżyć, emocji, dzięki którym będą mogli coś poczuć, przeczuć, i dzięki temu lepiej zrozumieć (Reimann, 2019).

$\mathrm{Na}$ drugim krańcu znajduje się podejście proponowane przez Leona Andersona (2014), tzw. autoetnografia analityczna (ang. analytic autoetnography). Stanowi ona strategię badawczą, polegającą na celowym i planowym dokonywaniu, w dłuższym przedziale czasowym aktów autoobserwacji podczas uczestniczenia w pewnym procesie społecznym. Badacz relacjonuje na bieżąco własne przeżycia i refleksje, utrwalając je np. $\mathrm{w}$ formie notatek terenowych czy dziennika autoobserwacji (Kacperczyk, 2014). Sednem tego podejścia jest systematyczny, etnograficzny (oparty na obserwacjach, wywiadach, notatkach) opis rzeczywistości wzbogacony o osobiste i subiektywne odniesienia badacza, jego odczucia i refleksje pojawiające się w trakcie procesu badawczego. Takie badanie było prowadzone $\mathrm{w}$ trakcie internetowego kurs jogi dla osób niewidomych z (użyciem platform do komunikacji) od marca $2020 \mathrm{r}$.

Proponowaną procedurę autoetnografii analitycznej Anderson charakteryzuje poprzez pięć kluczowych cech. Należą do nich:

1. Pełne uczestnictwo badacza w badanym środowisku (ang. Complete member researcher-CMR).

2. Refleksyjność analityczna. Zakłada ona „samoświadomą introspekcję, za którą stoi chęć lepszego zrozumienia zarówno siebie samego, jak i innych - poprzez analizowanie swoich działań i spostrzeżeń w odniesieniu do i w powiązaniu z działaniami i spostrzeżeniami innych" (Anderson, 2014, s. 153). Oznacza to, że interpretacje badawcze nie wyrastają z dokonywanych $\mathrm{z}$ dystansu odkryć, lecz stanowią efekt zaangażowanego dialogu z uczestnikami grupy. Co prowadzi nas do kolejnej charakterystyki:

3. Dialog z innymi informatorami niż ,ja" badacza. Ze względu na moje zakorzenienie $\mathrm{w}$ grupie, zdecydowałam się na prowadzenie obserwacji uczestniczącej, aktywnie angażując się w życie grupy, inicjując dyskusje, dzieląc się własnymi doświadczeniami i odczuciami. Poinformowałam osoby uczestniczące w zajęciach o tym, że chciałabym przeprowadzić naukową analizę naszej praktyki jogi. Zależało mi na tym, aby poznać indywidualne perspektywy innych osób niewidomych praktykujących wspólnie jogę, będących na początku swej drogi. W tym celu wykorzystałam różne techniki pozyskiwania danych. Było to podyktowane względami dostępności badań dla osób z niepełnosprawnością wzroku, zróżnicowanym poziomem umiejętności w zakresie obsługi ICT, a także indywidualnymi preferencjami w odniesieniu do sposobu dzielenia się swoimi doświadczeniami i refleksjami.

Z jednej strony, za zgodą uczestników zajęć, inicjowałam na forum grupy dyskusje na temat interesujących mnie zagadnień. Zazwyczaj odbywały się one $w$ trybie asynchronicznym z użyciem komunikatora WhatsAppp, który daje możliwość nagrywania wiadomości głosowych lub wysyłania wiadomości tekstowych. Wiadomości głosowe poddawałam transkrypcji. Udział w dyskusjach był dobrowolny, w związku z tym nie wszystkie osoby z grupy zdecydowały się na uczestniczenie $\mathrm{w}$ nich. W sumie udało mi 
się pozyskać opinie od pięciu kobiet. Na moje pytania na forum grupy na WhatsApp regularnie odpowiadały 3 uczestniczki zajęć. Z jedną uczestniczką, ze względu na jej preferencje, przeprowadziłam rozmowę $\mathrm{w}$ formie wymiany maili. Z kolejną rozmowa odbyła się w formule wywiadu ustrukturyzowanego na platformie Zoom.

Zależało mi też na tym, aby poznać perspektywę nauczycielek jogi pracujących z osobami niewidomymi. W tym celu przeprowadziłam 2 wywiady ustrukturyzowane $\mathrm{z}$ nauczycielkami, które są moimi przewodniczkami po praktyce jogi. Obie rozmowy odbyły się online z użyciem komunikatora Zoom.

Warto w tym miejscu nadmienić, że obecnie istnieją w Polsce dwie grupy jogiczne dla osób z dysfunkcją wzroku. Jedna z istniejących grup, z którą jestem związana od kilku lat, przed pandemią funkcjonowała $\mathrm{w}$ trybie stacjonarnym. W momencie ogłoszenia lockdownu zaczęła działać w trybie zdalnym. Druga grupa, wokół której koncentrują się moje analizy, została zainicjowana w trybie zdalnym już w czasie lockdownu. W moim przekonaniu jest to istotna zmienna wpływająca na procesy zachodzące w grupie: komunikację wewnątrz grupy, proces implementacji ICT w praktyce jogi oraz kontakt z nauczycielką, która nigdy nie poznała naszych ciał na żywo, ich możliwości, zakresów ruchowych itp. Stąd mój wybór, aby dogłębniej przyjrzeć się tej drugiej społeczności.

4. Obecność własnego „ja” badacza w prowadzonej narracji. Jest ono częścią danych niezbędnych do zrozumienia opisywanego świata społecznego. Jak pisze Anderson (2014, s. 155) „Z uwagi na podwójną rolę autoetnografa jako członka badanego przez siebie świata społecznego i jako badacza tego świata pisanie autoetnografii wymaga uwypuklenia obecności „ja” badacza w tekście. Obecność ta stanowi wyraz osobistego zaangażowania badacza w świat, który jest przedmiotem jego badań. Autoetnografowie powinni ilustrować swoje przemyślenia analityczne zarówno odwołaniami do doświadczeń i odczuć innych osób, jak do i swoich własnych”. Uczestnicząc w zajęciach jogi online, rozmawiając $\mathrm{z}$ osobami z grupy, w formie autorefleksji, często inspirowanych też przez zwerbalizowane myśli innych osób, regularnie zapisywałam moje myśli, refleksje związane z samą jogą i jej zapośredniczeniem przez ICT, a także z niewidzeniem. Niektóre z zebranych notatek postanowiłam zamieścić w niniejszym tekście.

5. Zaangażowanie w kwestie analityczne. analizę teoretyczną. Jak zauważa Anderson (2014, s. 158): „Celem autoetnografii analitycznej nie jest po prostu dokumentacja osobistych doświadczeń, aby zaprezentować „perspektywę insidera” ani też wywołanie w czytelniku emocjonalnego rezonansu. Specyficzną cechą analitycznie zorientowanych nauk społecznych jest raczej wykorzystywanie danych empirycznych do uzyskania wglądu w pewne szersze zjawiska społeczne niż te dostarczane przez dane same w sobie".

Ważną korzyścią analityczną, jaką oferuje autoetnografia, jest możliwość śledzenia powiązań pomiędzy jednostkową biografią a strukturą społeczną, które to powiązania stanowią sedno wyobraźni socjologicznej w ujęciu Charlesa W. Millsa. Kategoria wyobraźni socjologicznej jest inspirująca także w rozważaniach w zakresie studiów o niepełnosprawności (zob. Kowalska, Warat, Król, Migalska, 2014). Opisywaną praktykę jogi online umieszczę w szerszym kontekście rozważań o możliwościach i wyzwaniach, jakie niosą ze sobą dla osób niewidomych technologie informacyjne. Zacznę jednakże od charakterystyki sensów i znaczeń przypisywanych jodze przez osoby uczestniczące w zajęciach. 
Krzysztof Konecki (2012) zwraca uwagę na wielość rodzajów jogi oraz różnorodność potocznych jej definicji. W kulturze zachodniej joga jest definiowana głównie przez pryzmat ćwiczeń fizycznych, a najbardziej spopularyzowaną i praktykowaną na zachodzie odmianą jogi jest tzw. hatha-joga, która przykłada dużą wagę do praktyki fizycznej. Jej zadaniem jest wzmacnianie równowagi, elastyczności i siły. Praktyka ta polega na wyrównywaniu i kontrolowaniu oddechu, co ma prowadzić do powstania równowagi w ciele. „Dzięki takiej harmonii możliwe jest osiągniecie siły fizycznej, zdrowia fizjologicznego i dobrego samopoczucia emocjonalnego. Podstawowymi elementami zachodniej praktyki są asany - pozycje jogi - a także kontrola oddechu (pranajama)" (https://www. portalyogi.pl/blog/co-rozni-vinyasa-joge-od-ashtangi-iyaengar-i-hatha/).

Kareen Zebroff (2001, s. 7) zauważa, że praktyka jogi jest bardzo osobista, „jej główny akcent to osobiste postępy, których nie porównujemy z nikim innym, jak z samym sobą z dnia poprzedniego". Zwraca też uwagę na inkluzywność jogi, którą można ćwiczyć niezależnie od wieku, stanu zdrowia czy elastyczności stawów. Na włączający lub nie charakter zajęć zasadniczy wpływ ma otwartość nauczyciela lub jej brak. Sama joga jako forma aktywności fizycznej przyciągała mnie już od dawna. Natomiast mojego pierwszego spotkania z nią nie mogę uznać za udane. To był początek studiów, koleżanka namówiła mnie, żebym poszła z nią na zajęcia jogi. Mówiła, że jest super, że fantastycznie się po nich czuje. Zachęcona wybrałam się z nią do jednej z krakowskich szkół. Gdy nauczyciel mnie zobaczył, od wejścia powiedział, że nie będzie pracował z taką osobą jak ja (osobą niewidomą). Nie pamiętam, jak i czy w ogóle usprawiedliwiał swoją niechęć, strach przed być może bardziej wymagającą uczestniczką zajęć, której prawdopodobnie będzie musiał poświęcić nieco więcej czasu. Nawet dał mi namiar na jakąś inną szkołę, w której podobno instruktor prowadził jakąś grupę terapeutyczną. Jako że w owym czasie kategorycznie odżegnywałam się od wszystkiego, co miało w nazwie przymiotnik „terapeutyczny”, nigdy tam nie poszłam. Może zabrakło mi determinacji, chęci, straciłam motywację. Jednak teraz, dzieląc się refleksjami na forum grupy, nie mogę pominąć terapeutycznego wymiaru jogi i jej znaczenia w pracy nad akceptacją swojego ciała, które być może nie wygląda tak, jakbyśmy tego chciały, nie jest tak sprawne, jak byśmy tego oczekiwały, ciała, które ma niepełnosprawność. Jedna z uczestniczek zajęć ujmuje to w następujących słowach: Do tej pory miałam problemy z akceptacja siebie. Joga pomaga mi otwierać siebie na swoje ciało. Moge je zaakceptować, mimo że nie jest takie, jakie bym chciała. Nie jest szczupłe, nie jestem wysoka, nie jestem jakaś tam, ale jestem po prostu sobą. Powiem szczerze, że ćwiczac joge nawet czuję się piękna (U2 $\left.{ }^{1}\right)$.

Hatha-joga nie jest tylko narzędziem dbania o zdrowie fizyczne, lecz także przyczynia się do podnoszenia poziomu dobrostanu psychicznego i rozwoju duchowego jednostki (Stasińska, 2020). Dla niektórych z nas, oprócz znaczenia samorozwojowego, joga ma

\footnotetext{
${ }^{1}$ Wypowiedzi osób uczestniczących w zajęciach, które podzieliły się ze mną swoimi refleksjami, będę oznaczać literą $\mathrm{U}$, wypowiedzi nauczycieli - literą $\mathrm{N}$.
} 
znaczenie terapeutyczne, wspomaga leczenie depresji i stanów lękowych, może obniżać stres, wzmacniać wiarę w siebie i poczucie własnej wartości.

Te zajęcia sa mi potrzebne właśnie dlatego, żeby kształtować prawidłowe funkcjonowanie nie tylko ciała, ale też psychiki, bo joga uspokaja, wzbudza we mnie poczucie własnej wartości. Uświadamiam sobie możliwości swojego ciała, jego ograniczenia, to że jesteśmy potrzebne samym sobie. Joga to jest harmonia ciała i umysłu (U1).

Oczywiście joga może spełniać być może prozaiczną, lecz niezwykle ważną funkcję czysto rozrywkową i towarzyską. Wspólne regularne ćwiczenia budują poczucie przynależności do grupy osób podzielających m. in. doświadczenie niewidzenia czy słabowidzenia. Poczucie bycia w grupie jest szczególnie ważne w czasie pandemii, gdy sporo czasu spędzamy w domu, a nasza mobilność i kontakty towarzyskie są bardzo ograniczone.

Wymienione funkcje znaczenia jogi mają charakter uniwersalny. Czy zatem joga może mieć jakieś szczególne znaczenie w odniesieniu do osób z dysfunkcją wzroku?

Jedna z nauczycielek zauważa: Osoby niewidome w całym swoim życiu narażone sa na duże napięcia, właśnie spowodowane chociażby barierami, które sa na zewnątrz. Pokonujemy prosta trase z domu, nie wiem - do sklepu i z powrotem, po drodze mamy różne niespodzianki, pomimo że znamy tę trasę na pamięć, ale tu cośspadnie, tu słupek powstanie, tu ktoś wjedzie. To wszystko odkłada się $w$ ciele i powoduje napięcia, które w moim wyobrażeniu sa bardzo duże. No i trzeba coś zrobić, żeby te napięcia zlikwidować. Taka joga może pomóc $w$ likwidacji tych napięć, ale też $w$ świadomości swojego ciała: co jest z czym powiązane, co może ułatwić to życie. Takie było moje założenie (N2).

Temat stresu związanego z samodzielnym poruszaniem się po mieście kilkukrotnie pojawiał się w naszych rozmowach w grupie.

Możliwość samodzielnego przemieszczania się jest dla mnie ważna, natomiast teraz mogę powiedzieć, że często samo docieranie gdzieś jest dużo bardziej stresujące niż aktywność, którą muszę podjąć, np. poprowadzić warsztat czy wykład. Napięcia wiążą się z barierami architektonicznymi w postaci słupków, hulajnóg porzuconych byle gdzie, często na środku drogi. W szystko to odbiera poczucie bezpieczeństwa i pewności swoich ruchów. Do tego dochodzą liczne niechciane interakcje z ludźmi, którzy bardzo często zaczepiają mnie, bez werbalnego uprzedzenia chwytają za ramię, szarpią, próbują na siłę wpychać do windy. W takich sytuacjach tracę pewność siebie, wracam do domu wyczerpana fizycznie i psychicznie.

Prowadzone głównie w obszarze medycyny badania z udziałem osób z dysfunkcją wzroku wskazują, że regularna praktyka jogi znacząco poprawia zdolności proprioceptywne (tzw. czucie głębokie, czyli zmysł orientacji ułożenia części własnego ciała). Z uwagi na to, iż osoby niewidome mają ograniczoną możliwość wykorzystania zmysłu wzroku w poruszaniu się, wzmacnianie pozostałych układów sensorycznych, w tym zdolności proprioceptywnych, może wspomóc prawidłową koordynację ruchową, poczucie równowagi i stabilność postawy. Niewątpliwie kluczową rolę odgrywa tu praca nad świadomością własnego ciała, którą można osiągnąć przez uważne wykonywanie asan, praktyk oddechowych i medytacji (Jeter, Roach, Corson, Ryan, 2014; Mohanty, Pradhan, Nagathna, 2014; Jeter, Haaz Moonaz, Bittner, Dagnelie, 2015; Mohanty, Venkata Ramana Murty, Pradhan, Hankey, 2015; Mohanty, Hankey, Pradhan, Ranjita, 2016). 


\section{MOŻLIWOŚCI I WYZWANIA WYNIKAJĄCE Z PRAKTYKOWANIA JOGI ONLINE}

W czasie lockdownu technologie informacyjno-komunikacyjne (ang. ICT) z rozwiązań stanowiących alternatywę w edukacji, pracy, rozrywce stały się podstawowym kanałem realizowania tych aktywności.

Grupą, dla której już przed pandemią za sprawą ICT świat stał się bardziej otwarty i dostępny, są osoby z dysfunkcją wzroku. Umożliwiają to technologie asystujące, takie jak programy odczytu ekranu, programy powiększające ułatwiają osobom niewidomym i słabowidzącym komunikację, dostęp do informacji, swobodniejsze poruszanie się i nawigowanie po stronach internetowych a także poruszanie się w przestrzeni, np. miejskiej (Paplińska, 2015; Paplińska, 2018). Niemniej jednak, jak słusznie zauważa Małgorzata Paplińska (2015, s. 142), „nie-pełnosprawny wzrokowo użytkownik komputera musi wykazać się już nie tylko biegłością w obsłudze tego narzędzia, lecz także umiejętnościami bardziej zaawansowanymi, umożliwiającymi efektywne wykorzystanie technologii wspomagających". Wiąże się to z koniecznością ciągłego rozwijania różnorodnych kompetencji związanych ze sprawnym korzystaniem z ICT, w tym znajomości środowiska systemu Windows, Android, iOS.

Zróżnicowanie kompetencji cyfrowych jest bardzo widoczne w naszej kilkuosobowej grupie ćwiczącej jogę. Są wśród nas osoby, które można zaliczyć do kategorii „cyfrowych tubylców"2, czyli osób, które w środowisku ICT funkcjonują niejako naturalnie i bardzo sprawnie, na co dzień wykorzystując je w nauce i pracy. Pokazuje to ta wypowiedź: Ja w ogóle nie boję się technologii. Mi to wszystko wchodzi, mi to wszystko działa, mnie stucha. Technologia lubi mnie. Ja robiłam rzeczy online wcześniej też. Przez kilka lat prowadziłam lekcje angielskiego online, uczyłam grać na flecie. Powiem szczerze, że weszłam $w$ ten zdalny tryb totalnie bezboleśnie (U3).

Są jednak wśród nas osoby, dla których wymuszone lockdownem tak intensywne zanurzenie w środowisko ICT jest doświadczeniem nowym i często trudnym, powodującym stres i zagubienie. $\mathrm{Z}$ tego względu pierwszym wyzwaniem było znalezienie komunikatora, który byłby wygodny i dostępny dla osób o zróżnicowanych kompetencjach cyfrowych, aby z powodu ewentualnej niedostępności narzędzia nikt nie został wykluczony z uczestnictwa w ćwiczeniach. Lekcje jogi odbywają się z użyciem komunikatora Zoom, który daje możliwość prowadzenia zajęć $\mathrm{w}$ formie wideokonferencji dla większej grupy. Nieocenione jest tu wsparcie „cyfrowych tubylców”, którzy, zarówno nauczycielom, jak i uczestnikom zajęć udzielają pomocy i porad w zakresie obsługi komunikatorów, aplikacji z użyciem technologii asystujących na różnych systemach operacyjnych: ich instalacji, procesu rejestracji, aktualizacji oprogramowania,

\footnotetext{
${ }^{2}$ Pojęcie „cyfrowi tubylcy” (ang. digital natives) zaproponował Marc Prensky (2001). Mianem tym określił osoby, dla których „ojczyzną” jest świat technologii cyfrowych opartych na komunikacji w internecie. Dla „cyfrowych tubylców” komputer czy telefon podłączony do internetu stanowią podstawowe narzędzia do nauki, pracy czy rozrywki, są także naturalnym środkiem komunikacji międzyludzkiej i kreowania wizerunku.
} 
Dużym wyzwaniem okazało się być samo wchodzenie na zajęcia oraz ustawianie kamery w telefonie/tablecie/komputerze, tak aby instruktorka mogła widzieć osobę w trakcie wykonywania ćwiczeń i na bieżąco korygować asany. W tym kontekście ważne jest też oświetlenie pomieszczenia.

$\mathrm{Z}$ moich obserwacji wynika, że zawsze przed rozpoczęciem zajęć potrzebujemy ok. 10-15 minut na odpowiednie ustawienie kamer.

Jak zauważa jedna z nauczycielek: Kłopot też jest $w$ ustawieniu się. Czyli te pierwsze momenty. I to trwa przez kilka zajęć, żeby znaleźć to miejsce na komórkę, i żebym ja dała odpowiedni komunikat, jak ta komórka ma być ustawiona względem maty. No bo teraz ja mówię, że daj bardziej w prawo. Ale co w prawo - czy telefon, czy matę, czy siebie. I to jest bardzo dlugi i żmudny proces. (...) To jest chyba największe wyzwanie, bo tutaj sa kierunki: prawo, lewo, góra, dót, co ja widzę, czego nie widzę (N2).

Początkowo organizowaliśmy próby dla osób, które nigdy nie ćwiczyły online, aby mogły opanować obsługę narzędzia do komunikacji oraz ustawianie kamery. Dla mnie to była abstrakcja, że można komuś wydawać instrukcje przez iPhone, jak ma ćwiczyć (U1).

Zoom nie ma interfejsu w języku polskim, co początkowo przysparzało niektórym osobom trudności związanych ze zrozumieniem komunikatów programu. $W$ ogóle nie miałam pojęcia, kto to jest ten caly host, co to jest poczekalnia. Jak to jest, że się coś naciska $i$ jest się w poczekalni. Dla mnie to była abstrakcja (U1).

Inne wyzwania, jakie pojawiły się w toku zajęć, to:

- Ustawienie dźwięku, tak aby nie było sprzężenia zwrotnego i aby dźwięki tła nie przeszkadzały innym w praktyce. Tu istotna jest jakość słuchawek, które powinny mieć połączenie Bluetooth oraz mikrofon. Ze względu na brak kontaktu wzrokowego z nauczycielem musimy utrzymywać ciągły kontakt słowny, dlatego całkowite odcięcie dźwięków z otoczenia poprzez wyciszenie mikrofonu nie jest możliwe.

- Zarówno po stronie nauczyciela, jak i uczestników zajęć, konieczne jest dobre łącze internetowe - minimum 10 mbps. Łącze o takich parametrach jest konieczne do przeprowadzenia komfortowej transmisji wideo bez opóźnień w przesyłaniu obrazu i dźwięku. Wszelkie przerwy w transmisji zakłócają komunikację z nauczycielem, powodują utratę płynności wykonywanych ćwiczeń, a tym samym - znaczące pogorszenie jakości praktyki, która ma służyć pracy nad koncentracją i wyciszeniem negatywnych emocji, natłoku myśli.

- Przed rozpoczęciem zajęć należy zadbać o naładowanie urządzenia, przez które będziemy się łączyć - do minimum 50\%, ponieważ przy zbyt niskim poziomie naładowania baterii, $\mathrm{w}$ ramach oszczędzania energii, następuje przerwanie transmisji wideo.

\section{KOMUNIKACJA W GRUPIE}

Nasza bieżąca komunikacja, dotycząca udziału w zajęciach, płatności, naszych wrażeń i refleksji związanych z jogą, odbywa się z użyciem aplikacji WhatsApp. To darmowy mobilny komunikator umożliwiający wysyłanie wiadomości tekstowych lub wiadomości 
głosowych. Aplikacja jest dostępna na systemach mobilnych: Android, iOS i spełnia standardy dostępności dla osób niewidomych.

Staramy się zapanować nad wielością i długością wysyłanych wiadomości głosowych, sygnalizując na początku każdej wiadomości jednym słowem, czego ona będzie dotyczyć, np. „hasztag joga”, „hasztag inne”. Staramy się nie nagrywać wiadomości dłuższych niż pięć minut.

Wiadomości tekstowe to po prostu suchy, krótki tekst - niezbędna informacja, bez żadnych ozdobników, ewentualnie jakieś emotikonki typu :) lub :- Wiadomości głosowe zawsze są nagrywane w jakiejś przestrzeni, zawsze mają jakieś dźwiękowe tło. Do połowy czerwca $2020 \mathrm{r}$. zwykle była to przestrzeń domu, która może być bardzo różnorodna i bogata w dźwięki. Czasem w tle słychać muzykę, włączony telewizor, szum gotującej się w czajniku wody, głosy innych domowników. Jeśli ktoś dysponuje ogrodem czy balkonem, czasem w tle słychać śpiew ptaków.

Stopniowo zaczynamy wychodzić z izolacji, podróżować np. komunikacją miejską. Coraz częściej tłem wiadomości są odgłosy miasta, szum samochodów, wnętrze autobusu, głosy innych ludzi, okrzyki bawiących się dzieci, stukot białej laski o chodnik w trakcie przemieszczania się. W wiadomościach głosowych da się rozpoznać, czy ktoś ma maseczkę na twarzy. Wtedy głos jest trochę przytłumiony, nie odbija się w przestrzeni. Tło wiadomości jest dla mnie równie interesujące, jak ich główna treść. Dzięki niemu mogę sobie wyobrazić sytuację, w której znajduje się dana osoba, jak stoi na przystanku, siedzi w autobusie, idzie ulicą, przewraca się w łóżku.

Nagrywanie wiadomości ma w sobie coś intymnego. Czuję się tak, jakby ktoś zapraszał mnie do swojego domu, pozwalał zajrzeć do swojej prywatnej przestrzeni. Początkowo nagrywanie wiadomości do grupy było dla mnie krępujące. Częściej piszę niż nagrywam. Muszę przepracować te mikromonologi, które oczywiście trafią do grupy i potem staną się częścią jakiejś dyskusji, wymiany myśli, ale w procesie tworzenia mają charakter monologu, mikroopowiadania, rozmowy samej do siebie przez telefon. Początkowo moje wiadomości są krótkie - kilka sekund, z czasem udaje mi się nagrać dłuższy wywód na jakiś temat.

\section{PRAKTYKA JOGI DLA OSÓB NIEWIDOMYCH Z PERSPEKTYWY NAUCZYCIELEK}

W tym miejscu przyjrzę się perspektywie nauczycielek jogi prowadzących zajęcia z osobami z niepełnosprawnością wzroku. Jakie wyzwania wiążą się dla nich w pracy z tą grupą, jakie nowe umiejętności w zakresie nauczania jogi musiały rozwinąć?

Moje rozmówczynie zwracają uwagę na uniwersalność praktyki jogi: Tak naprawdę joga jest w ciele. Można ja ćwiczyć z zamkniętymi oczami. (...) To, że ktoś nie widzi- żaden problem. Bardziej ograniczenia $w$ ciele sa problemem, jak osoby sa $n p$. otyłe albo mało rozciagnięte $(\mathrm{N} 1)$.

Dla osób niezakorzenionych w świecie cyfrowym trudnością może być sama forma zajęć online, która wymaga od prowadzącego formułowania precyzyjnych komunikatów, jednocześnie wyklucza możliwość manualnej korekty asan. 
Jedyne, co, chyba mam wrażenie, że różni się dlatego, że jest online. I wtaśnie nie moge podejść, nie mogę kogoś skorygować, nie moge dotknąć. Jeden dotyk, jedno przestawienie dłoni daje o wiele więcej niż 30 zdań moich na ten temat (N1).

Zasadnicza różnica $\mathrm{w}$ prowadzeniu zajęć dla osób niewidomych w porównaniu do zajęć prowadzonych dla osób widzących manifestuje się w języku, który musi być bardzo dokładny i precyzyjny. To, co jest największym wyzwaniem $w$ prowadzeniu jogi dla niewidomych, że ja nic nie pokazuje. (...) Ja to nazywam, że to jest joga mówiona, bo wymaga ode mnie mówienia $i$ to nie takiego mówienia, jak normalnie na innych zajęciach, bo ja muszę mówić dość precyzyjnie o każdym ułożeniu ciała, aż do palców dłoni czy stóp (N2).

$\mathrm{Na}$ każdych zajęciach stajemy przed wyzwaniem uwspólniania kodów językowych, różnych określeń, terminów. Nauczyciel musi formułować z jednej strony bardzo konkretne, z drugiej - zrozumiałe dla wszystkich komunikaty. Cały czas jest to praca z wyobraźnią, polegająca na poszukiwaniu plastycznych, obrazowych metafor.

Często to sa komunikaty wypracowane w trakcie, jak chociażby jedna $z$ takich rzeczy, które przewijały się i długo nie mogłam znaleźć, jak powiedzieć, żeby ułożyć ręce prostopadle względem ciała. I to było na tyle niezrozumiałe, że na zajęciach ustaliliśmy swój kod; i to jest ułożenie rąk „na Chrystusa”, co się okazało, niezależnie, czy ktoś wierzy, czy nie wierzy, ale raczej większość wie, jak Chrystus wisiał na krzyżu i wie, co z tymi rękoma zrobit. (...) I tych komunikatów takich nowych, niejogowych zupelnie jest trochę. To jest taki swoisty język wytworzony w trakcie pomiędzy mna a grupa (N2).

Kluczem jest tu współpraca $\mathrm{z}$ grupą $\mathrm{w}$ wypracowywaniu adekwatnych i trafnych komunikatów. Nauczyciel powinien opanować umiejętność „dotykania słowem”, słownego korygowania asan, co może zajmować nieco więcej czasu i wymagać językowej kreatywności i elastyczności.

Więcej używam zwrotów odnoszących się do innych zmysłów: do dotyku, do kształtu, do wyglądu czegoś, co można dotknąć. (...) Pomagaja mi na pewno książki, które mam. Czasami mając $z$ wami lekcje, biorę książki, bo tam sa bardzo konkretnie i bardzo opisowo podane pojęcia i polecenia. (...) Tam użyte sa stowa $z$ fizjologii zaczerpnięte. Jak mam dzień z gorsza percepcją, to się tym wspomagam (N1).

\section{JOGA ONLINE CZY OFFLINE?}

Zadałam sobie i innym pytanie, czy ta forma ćwiczeń może mieć jakąś przewagę nad ćwiczeniami w studio, szkole jogi? Odpowiedź nie jest jednoznaczna. Każda z tych form praktykowania jogi ma niewątpliwe plusy, ale i minusy. Ze względu na brak fizycznego kontaktu z nauczycielem część osób uznaje praktykowanie jogi online za połowiczne, niepełne.

Zajęcia online nigdy nie sa tak samo wartościowe, jak zajęcia na żywo, gdzie ja moge dotknąć trenera, czy on może podejść do mnie i dokładnie mi pokazać, co i jak (U4).

Ustne prowadzenie ćwiczeń jest jak najbardziej możliwe i przynosi dobre rezultaty, jednakże nie wszystkie asany można wykonać bez fizycznej asekuracji nauczyciela, szczególnie na etapie początkującym, gdy świadomość ciała dopiero się rozwija i wzmacnia. Wykonywane samodzielnie zaawansowane asany mogą doprowadzić do kontuzji. 
Jedno, czego ja się nie podejmę, prowadzac zajęcia online, to polecenia, aby uczestniczki zajęć stawaly np. na głowie czy na rękach, albo robiły mostek, tzn. takie pełne wygięcie do tyłu. Ja nie wezmę takiej odpowiedzialności na siebie, bo nie przytrzymam tej osoby, gdyby coś się działo. To sa rzeczy, które mogę zrobić tylko i wyłącznie w realu - w sali (N2).

Inne ograniczenia wynikające z zapośredniczenia zajęć przez ICT, to pojawiające się często $\mathrm{w}$ trakcie praktyki zakłócenia w transmisji wynikające ze słabego łącza internetowego: dekoncentrują, zaburzają komunikację a tym samym możliwość pełnego doświadczenia jogi.

Joga online jest połowiczna. Ja mam zupetnie inna energię, jak ćwicze z grupa, moge mieć bezpośredni kontakt z tymi ludźmi. Energia zupetnie inaczej plynie. Przez komputer ona się rozprasza. Czasami u kogoś przerywa. Takie techniczne rzeczy rozbijają te zajęcia. Wyzwaniem jest, żeby caly czas mieć tę wysoka świadomość, wysoką energie, wysoką chęć do działania (N1).

Mimo tych ograniczeń zdalna praktyka jogi ma kilka kluczowych zalet, które są szczególnie istotne dla osób z niepełnosprawnością wzroku. Osoby uczestniczące w zajęciach zwracają uwagę na przełamywanie bariery mobilności. Ćwiczenia odbywają się w domu, w znanej, oswojonej przestrzeni. Większość osób bardzo sobie chwali, że jest to online, bo przede wszystkim osoby sq u siebie $w$ domu i czuja się bezpiecznie. Nie musza nigdzie wychodzić, sa niezależne od pogody, od wtasnego samopoczucia (N2).

Wyjście do szkoły jogi wymaga większego wysiłku, nauczenia się nowej trasy. Jeśli myślimy o osobach niewidomych, to myśle, że tak. Ponieważ jeżeli chciałabyś dojeżdżać do szkoły jogi, to musisz poznać trasę. Jeśli sama umiesz się poruszać, to musisz z kimś tę trasę opracować. Jeśli nie jesteś na tyle samodzielna, że nie poruszasz się, tak jak ja, no i jeszcze musisz dojeżdżać, no to lepsza jest taka metoda prowadzenia jogi (U2).

$\mathrm{Z}$ doświadczenia wiem, że miejsca takie, jak siłownie czy kluby fitness często są niedostępne. Wciąż musimy się zderzać $\mathrm{z}$ wykluczającymi postawami instruktorów i trenerów, którzy prowadząc zajęcia dla osób widzących, nie muszą opowiadać wykonywanych ćwiczeń w sposób obrazowy. Ponadto dla części osób tempo takich zajęć może być zbyt szybkie. Instruktorzy nie zawsze chcą podejmować dodatkowy wysiłek związany ze zwracaniem większej uwagi na osobę, która ma inne potrzeby, zwracania uwagi na język, żeby był bardziej opisowy. Znalezienie dostępnego dla nas klubu czy szkoły może wymagać dodatkowego wysiłku w poszukiwaniu, zbieraniu informacji, opracowywaniu nowej trasy. Niekoniecznie musi być to miejsce znajdujące się w pobliskiej okolicy - na naszym osiedlu.

Trudno mi się zmobilizować do chodzenia na zajęcia do jakiegoś studia, szkoły i do uczestnictwa w nich $z$ osobami widzacymi. Jest bariera ze strony nauczycieli, że nie chca przyjmować takich osób. To nie jest takie oczywiste, że sobie pójdziesz do jakiejś tam szkoły i przyjma cię z otwartymi ramionami. (...) Odpowiada mi, że sa zajęcia dedykowane nam, ponieważ nauczyciel dostosowuje ich formę i tempo do naszych możliwości (U3).

W zajęciach uczestniczą osoby mieszkające w różnych częściach Polski, osoby z dużych miast i z małych miejscowości, w których być może nie ma rozbudowanej infrastruktury sportowej; osoby, które z powodu ograniczonej mobilności rzadziej wychodzą $\mathrm{z}$ domu, mniej się ruszają, osoby doświadczające wykluczenia transportowego. 
Ważne jest też, że praktyka online we własnym domu daje nam poczucie anonimowości i spokoju, który w sali, w grupie osób widzących może być zaburzany przez nasze subiektywne poczucie hiperwidzialności niepełnosprawności. Poczucie to, prawdziwe czy wyobrażone, może być na tyle niekomfortowe, że odbiera radość czerpaną z samych ćwiczeń.

Osoby zgłaszały, że nie miałyby śmiałości wyjść tak przed grupe, że nie chciałyby np. $w$ grupie ćwiczyć, że wola być same, indywidualnie. I tutaj $w$ zasadzie jest joga indywidualna, bo nie ma nikogo obok. Jestem sam na sam $z$ ta osobą. I to też dużo daje, bo część osób nie chce w grupie. I to dla nich jest dużo wygodniejsze (N2).

Niedaleko mnie jest siłownia. Tylko że ja chyba mam psychiczny problem z ćwiczeniem przy innych osobach, w tłoku, hałasie, krępuje mnie to. Może to jest jakiś kompleks wynikajacy z niewidzenia i braku możliwości weryfikacji, ale ciagle mam wrażenie, że jestem obserwowana. Pewnie po części jest to prawda, no bo niestety większość ludzi, jeśli wie, że jest ktoś taki wśród nich, to choćby ukradkiem, ale zerkaja, żeby sprawdzić, jak sobie radzi. Czy to jest kwestia krytyki czy podziwu, czy czystej ciekawości, tak czy inaczej odbiera mi to możliwość wyciszenia się, anonimowości, której się czasami potrzebuje. I ja nie umiem chodzić na zajęcia grupowe z osobami widzacymi, nieznajomymi zupetnie, to totalnie odpada. A gdybym miała chodzić na indywidualne, to by mnie pewnie nie było stać (U5).

Online z jednej strony każdy z nas ćwiczy w swojej oswojonej przestrzeni, z drugiej strony jesteśmy ze sobą połączeni, możemy czerpać energię od siebie nawzajem i wzajemnie się motywować, wzmacniać.

Rozwiązania, jakie niosą ze sobą ICT, mają ogromny potencjał w przełamywaniu ograniczeń czasu, przestrzeni i ogólnie rozumianej fizyczności (Masłyk, Migaczewska, 2014). Praktykowanie jogi za pośrednictwem ICT zdecydowanie pokonuje ograniczenia związane z przestrzenią. Nie jestem zależna od miejsca, w którym jestem. Ja też np. się przemieszczałam i prowadziłam zajęcia skądś, bo akurat wyjechałam. I normalnie nie poprowadziłabym zajęć, a jednak ważna jest ciągłość, nawet raz $w$ tygodniu, ale systematycznie (N2).

\section{ZAKOŃCZENIE}

Rozwój technologiczny niewątpliwie służy poprawie jakości życia osób niepełnosprawnych. Wydaje się, że grupą, której rozwój ICT sprzyja szczególnie, są osoby z dysfunkcją wzroku. Nowe technologie umożliwiają nam funkcjonowanie w dawniej trudnodostępnych obszarach życia (Paplińska, 2018). Od czasu rozpoczęcia studiów komputer wyposażony $\mathrm{w}$ technologie asystujące, $\mathrm{w}$ tym program odczytu ekranu, jest moim nieodłącznym towarzyszem życia i narzędziem niezbędnym w nauce i pracy. Natomiast możliwość ćwiczeń zapośredniczonych przez ICT jest dla mnie ogromnym odkryciem. W czasie pandemii technologia odsłoniła przede mną jeszcze jeden emancypacyjny wymiar i pole do niezależnego funkcjonowania. Przede wszystkim pozwala nam przekraczać bariery związane $\mathrm{z}$ mobilnością, wynikającą nie tylko z dysfunkcji wzroku, lecz także z miejsca zamieszkania i wykluczenia transportowego. Jedna z uczestniczek zajęć ujęła to tak: Technologia 
daje nam mnóstwo wspaniałych możliwości. To tak, jakby nie musieć już iść przez nierówne chodniki (U3).

Niemniej jednak ICT wymagają od nas ciągłego nabywania nowych umiejętności związanych $\mathrm{z}$ ich użytkowaniem oraz zwiększania swoich kompetencji w tym zakresie. Systemy operacyjne, aplikacje mobilne ciągle są aktualizowane, co wymaga bezustannego uczenia się nowych poleceń i funkcji. U części osób może powodować to duży stres i zagubienie. W przełamywaniu lęków związanych z wchodzeniem w świat ICT ogromną rolę odgrywają "cyfrowi tubylcy” - osoby biegle posługujące się ICT, które udzielają wsparcia w zakresie korzystania $\mathrm{z}$ nich. 


\section{BIBLIOGRAFIA}

Anderson, L. (2014). Autoetnografia analityczna. Przegląd Socjologii Jakościowej, 10 (3), 144-167.

Bielecka-Prus, J. (2014). Po co nam autoetnografia? Krytyczna analiza autoetnografii jako metody badawczej. Przegląd Socjologii Jakościowej, 10 (3), 76-95.

Jeter, P.E., Roach, C., Corson, M., Ryan, C. (2014). Yoga Reduces Fear of Falling and Negative Psychosocial States in Persons with Visual Impairment. Journal of alternative and complementary medicine, 20 (5), A57. https://doi.org/10.1089/acm.2014.5149.abstract

Jeter, P.E., Haaz Moonaz, S., Bittner, A.K., Dagnelie, G. (2015). Ashtanga-Based Yoga Therapy Increases the Sensory Contribution to Postural Stability in Visually-Impaired Persons at Risk for Falls as Measured by the Wii Balance Board: A Pilot Randomized Controlled Trial. PLOS ONE, 10 (6), e0129646. https://doi.org/10.1371/journal.pone.0129646

Kacperczyk, A. (2014). Autoetnografia - technika, metoda, nowy paradygmat? O metodologicznym statusie autoetnografii. Przegląd Socjologii Jakościowej, t. 10, nr 3, 32-74.

Konecki, K.T. (2012). Czy ciało jest świątynią duszy? Współczesna praktyka jogi jako fenomen psychospołeczny. Difin.

Kowalska, B., Warat, M., Król, A., Migalska, A. (2014). Studia nad niepełnosprawnością a wyobraźnią socjologiczną. Studia socjologiczne, 213(2), 225-250.

Mohanty, S., Pradhan, B., Nagathna, R. (2014). The Effect of Yoga Practice on Proprioception in Congenitally Blind Students. British Journal of Visual Impairment, 32 (2), 124135. https://doi.org/10.1177/0264619614522132

Mohanty, S., Venkata Ramana Murty, P., Pradhan, B., Hankey, A. (2015). Yoga Practice Increases Minimum Muscular Fitness in Children with Visual Impairment. Journal of caring sciences, 4(4), 253-263. https://doi.org/10.15171/jcs.2015.026

Mohanty, S., Hankey, A., Pradhan, B., Ranjita, R. (2016). Yoga-teaching protocol adapted for children with visual impairment. International Journal of Yoga, 9 (2), 114-120. https:// doi.org/10.4103/0973-6131.183716

Paplińska, M. (2015). Młode pokolenie osób z niepełnosprawnością wzroku w paradoksie informacyjno-komunikacyjnym. W: K. Czerwińska, M. Paplińska, M. Walkiewicz-Krutak (red.), Tyflopedagogika wobec współczesnej przestrzeni edukacyjno-rehabilitacyjnej (136-155). Akademia Pedagogiki Specjalnej.

Paplińska, M. (2018). Technologie informacyjno-komunikacyjne a jakość życia osób z niepełnosprawnością wzroku. W: K. Parys, M. Trojańska, A. Ochman (red.), Teoria i praktyka oddziaływań profilaktyczno-wspierających rozwój osób z niepełnosprawnością - wobec pytań i odpowiedzi o dobrostan człowieka (184-195). Wydawnictwo Naukowe UP.

Portalyogipl. https://www.portalyogi.pl/blog/co-rozni-vinyasa-joge-od-ashtangi-iyaengar-ihatha/

Prensky, M. (2001). Digital Natives, Digital Immigrants Part 1. On the Horizon, 9 (5), 1-6. https://doi.org/10.1108/10748120110424816

Reimann, M. (2019). Nie przywitam się z państwem na ulicy. Szkic o doświadczeniu niepełnosprawności. Wydawnictwo Czarne. 
Stasińska, A. (2020). Czy joga może być „sztuką życia”? Przegląd badań na temat jogi jako zjawiska społecznego. Przegląd Socjologii Jakościowej, 16 (4), 170-190.

Zebroff, K. (2001). Joga dla każdego. praktyka, specjalne programy ćwiczeń, techniki oddechowe. ABA Oficyna Wydawnicza. 